\title{
Anti-Hyperglycaemic and Anti-Oxidative Effect of Merremia Tridentata (Linn) Hallier F Ethanol Leaf Extract
}

\author{
Olubodun A. Adebiyi, Danladi A. Ameh, Elewechi Onyike, and Dorcas B. James
}

\section{ABSTRACT}

The anti-hyperglycaemic and anti-oxidative effect of Merremia tridentata (Linn) Hallier F ethanol leaf extract (MTELE) was evaluated in this study. Diabetes was induced on male albino wistar rats by a single intra-peritoneal injection of $65 \mathrm{mg} / \mathrm{kg}$ body weight dose of streptozotocin. The rats were divided into seven groups and treated accordingly with varying doses $(50 \mathrm{mg} / \mathrm{kg}, 75 \mathrm{mg} / \mathrm{kg}$ and $100 \mathrm{mg} / \mathrm{kg}$ body weight) of MTELE for seven weeks. Body weight and plasma glucose levels were monitored while antioxidant parameters, catalase (CAT), superoxide dismutase (SOD) activities, reduced glutathione (GSH) concentration and levels of thiobarbituric acid reacting substances (TBARS) were determined in the liver and kidney tissues. There was a significant $(p<0.05)$ reduction in the weight of the diabetic control group which was significantly $(p<0.05)$ ameliorated by the treatment. Plasma glucose levels were significantly $(p<0.05)$ reduced by $50.6 \%, 62.1 \%$ and $72.68 \%$ in diabetic rats treated with $50 \mathrm{mg} / \mathrm{kg}, 75 \mathrm{mg} / \mathrm{kg}$ and $100 \mathrm{mg} / \mathrm{kg}$ body weight dose of MTELE respectively. There was a significant $(p<0.05)$ improvement in all the antioxidant parameters investigated in this study in both the liver and kidney tissues at all levels of treatment (increase in the activities of CAT and SOD, increase in tissue content of GSH and drastic reduction of TBARS level). The extract at $100 \mathrm{mg} / \mathrm{kg}$ body weight dose on normal rats showed a significant $(\mathbf{p}<0.05)$ improvement in the status of SOD in the kidney, GSH and TBARS in the liver when compared with the normal control group. MTELE demonstrated a good anti-hyperglycaemia and antioxidant potential and should be further investigated for development of lead compound capable of preventing and treating oxidative stress related complications in diabetics.

Keywords: Anti-hyperglycaemic, Anti-oxidation, Merremia tridentata, Liver and Kidney.
Published Online: February 05, 2022 ISSN: $2684-4478$

DOI: 10.24018 /ejchem.2022.3.1.87

\section{O. A. Adebiyi*}

Department of Biochemistry, Ahmadu Bello University, Zaria, Nigeria.

(e-mail: olubodunadebiyi@ gmail.com) D. A. Ameh

Department of Biochemistry, Ahmadu Bello University, Zaria, Nigeria.

(e-mail: danladiameh@yahoo.com) E. Onyike

Department of Biochemistry, Ahmadu Bello University, Zaria, Nigeria.

(e-mail: elewechi2003@yahoo.com)

D. B. James

Department of Biochemistry, Ahmadu Bello University, Zaria, Nigeria.

(e-mail: dbjams16187@yahoo.com)

*Corresponding Author

\section{INTRODUCTION}

Merremia tridentata (Linn) has been used in herbal medicine in the treatment of scorpion sting, urinary tract infection and gonorrhea. In Nigeria, the plant is used in the treatment of diabetes mellitus and other sugar related diseases. The anti-diabetic effect of the aqueous root extract of the plant in streptozotocin induced diabetic rat had been reported [1]. Diabetes mellitus is a very devastating disease ravaging the populace in both rural and urban settings. It is characterized by persistent hyperglycaemia and oxidative stress which is a major contributory factor to diabetic complications like retinopathy and nephropathy [2]. The reactive oxygen species generated as a result of oxidative stress are usually scavenged by the enzymes involved in oxidative stress defense mechanism [3]. Diabetes is known to cause derangement in the activities of antioxidant enzymes such as Catalase (CAT), Superoxide dismutase (SOD, glutathione reductase and peroxidase (GSSG-R and GSHPx) and also in the levels of non-enzymatic antioxidants [4].

The effectiveness of extracts of different parts of plants in the management of the characteristic symptoms in diabetes had been severally reported [5]-[9]. These reports supported the claims of herbal practitioners in different continents on the possibility of ameliorating the devastating scourge of the disease using plant materials. Plants have been depended on by man as a source of his food and medication since ancient times. These green organisms have been found to contain both notable primary and beneficial secondary metabolites which had led to the extraction, purification, characterization, and synthesis of lead compounds of immense therapeutic importance. Reference [10], reported the anti-inflammatory and antiarthritic activities of the plant while the aqueous root extract has been found to possess anti-diabetic potentials in experimental animals [1]. Personal communication of a patient bid for possible limb amputation as a result of diabetic complication testified to amelioration of the condition and reversal of the doctor's decision to amputation. These reports had spurred further interest to study the other parts of the 
plants for anti-diabetic activities.

There is paucity of reports on the anti-oxidative potential of Merremia tridentata ethanol leaf extract (MTELE) in the liver and kidney tissues. Most of the common anti-diabetic drugs are associated with unwanted side effects making antioxidants from natural sources promising in the protection against oxidative stress induced complications due to diabetes. In the present study, the anti-hyperglycemic and anti-oxidative effects of ethanol leaf extract of Merremia tridentata (Linn) Halier F on the liver and kidney have been investigated in streptozotocin induced diabetic rats.

\section{MATERIALS AND METHOD}

\section{A. Plant Material and Extraction}

The aerial part of Merremia tridentata was collected from the bank of Tamburawa River along Zaria road Kano Nigeria and was authenticated at the Herbarium unit of Botany department of Ahmadu Bello University Zaria, Nigeria. The plant material was shade dried for three weeks to allow the leaves to drop from the stem and pulverized using a kitchen blender. The powdered leaf sample $(500 \mathrm{~g})$ was cold macerated using 70\% ethanol (1.5 liters) for seventy two hours after which the solvent was evaporated using Rotary Vacuum Evaporator (Hahn Vapor, HS-2005V, Hahn Shin Scientific Co., Korea) to obtain the Merremia tridentate Ethanol leaf extract (MTELE) used for this study.

\section{B. Animals}

Healthy adult albino male rats weighing 130 to $150 \mathrm{~g}$ were obtained from National Animal Production and Research Institute (NAPRI, Vom, Nigeria) were grouped and housed in cages under 12 hours light dark cycle at $34 \pm 2{ }^{\circ} \mathrm{C}$ with free access to standard pellet diet and water ad libitum. The animals were allowed to acclimatize to the laboratory conditions for two weeks prior to the commencement of the experiment. The animals were administered $65 \mathrm{mg} / \mathrm{kg}$ body weight dose of streptozotocin intraperitoneally after an overnight fast and sugar solution provided. The blood sugar level of the rats was monitored with a glucometer for a period of five days while the rats with blood glucose level of $17 \mathrm{mmol} / \mathrm{L}$ and greater were included in the experiment. Thirty five male albino rats were group into seven of five per cage and treated as follows:

Group I: Normal rat administered $0.2 \mathrm{ml}$ of distilled water;

Group II: Diabetic rats treated with $0.2 \mathrm{ml}$ of distilled water;

Group III: Normal rats treated with MTELE (100mg/kg body weight/day);

Group IV: Diabetic rats treated with MTELE (50mg/kg body weight/day);

Group V: Diabetic rats treated with MTELE ( $75 \mathrm{mg} / \mathrm{kg}$ body weight/day);

Group VI: Diabetic rats treated with MTELE (100mg/kg body weight/day);

Group VII: Diabetic rats treated with Glibenclamide ( $1 \mathrm{mg} / \mathrm{kg}$ body weight/day).

Treatment of the animals was carried out for seven weeks by oral gavage. The weights of the animals were monitored on weekly basis and the animals were sacrificed humanely under anaesthesia with the harvest of blood through cardiac puncture while liver and kidney were harvested through dissection.

Liver and kidney tissues were thoroughly washed in ice cold saline and homogenized in a PotterElvehjem homogenizer using ice-cold 50mM phosphate buffer containing Protease inhibitor cocktail. The homogenates were centrifuged at $12,000 \mathrm{x}$ g for 30 minutes and the supernatants used for the assay of antioxidant markers.

\section{Chemicals}

Streptozotocin, epinephrine, glibenclamide and mammalian protease inhibitor cocktail were purchased from Sigma Chemical Company Inc., St Louis, Mo, USA. All other chemicals used were purchased from Fulka Chemicals Nigeria Ltd. and they are of analytical grade.

\section{Biochemical Assay}

Blood samples of the rat were collected through the tail vein on the fifth day after diabetic induction with streptozotocin and forty nine days after MTELE administration after an overnight fast to determine the fasting blood glucose using a glucometer. Protein determination of the homogenates was carried out according to the protocol of [11] using bovine albumin as a standard at $660 \mathrm{~nm}$.

\section{E. Estimation of Tissue Antioxidants (SOD, CAT, GSH and TBARS)}

The method of [12] was used to assay superoxide dismutase (SOD) activity. The assay mixture total volume of $3.0 \mathrm{ml}$ is made up of $1.5 \mathrm{ml} 0.1 \mathrm{M}$ carbonate-bicarbonate buffer (pH 10.3), $0.1 \mathrm{ml} 30 \mathrm{mM}$ EDTA, suitable aliquot of enzyme preparation and water to make up the volume to $2.94 \mathrm{ml}$. Initiation of the reaction was done by the addition of $0.06 \mathrm{ml}$ of $15 \mathrm{mM}$ epinephrine. Change in absorbance was read at $480 \mathrm{~nm}$ for one minute at 15 seconds interval alongside the control which contained all ingredients except the enzyme preparation. One unit of enzyme activity was defined as that which caused $50 \%$ inhibition of auto-oxidation of epinephrine by $1.0 \mathrm{ml}$ of homogenate. 
The method of [13], as described by [14] was employed in the assay of catalase (CAT) in the tissues homogenate. Briefly the assay mixture of total volume $1.6 \mathrm{ml}$ was made up of $1.0 \mathrm{ml}$ of $0.01 \mathrm{M}$ phosphate buffer (pH 7.0), $0.1 \mathrm{ml}$ of tissue homogenate supernatant and $0.5 \mathrm{ml}$ of $2.0 \mathrm{M}$ hydrogen peroxide $\left(\mathrm{H}_{2} \mathrm{O}_{2}\right)$. The reaction was stopped by adding $2.0 \mathrm{ml}$ dichromate acetic acid reagent (mixture of $5 \%$ potassium dichromate and glacial acetic acid in 1:3 ratio) and absorbance read at 570 nm. The activity was expressed as $\mu$ moles $\mathrm{H}_{2} \mathrm{O}_{2}$ decomposed $/ \mathrm{min} / \mathrm{mg}$ protein.

Reduced glutathione (GSH) concentration was measured according to [15] as described by [16]. To $150 \mu \mathrm{L}$ of tissue homogenate, $1.5 \mathrm{ml}$ of $10 \%$ TCA was added and centrifuged at $1500 \mathrm{xg}$ for 5 minutes. Then $1 \mathrm{ml}$ of supernatant was mixed with $0.5 \mathrm{ml}$ of Ellman's reagent and $3.0 \mathrm{ml}$ of phosphate buffer. The absorbance was read at $412 \mathrm{~nm}$ against referenced blank containing $150 \mu \mathrm{L}$ of distilled water. Reduced glutathione $(\mathrm{GSH})$ concentration was calculated using a standard concentration of L-glutathione.

The determination of lipid peroxidation was based on the reaction of TBARS (Thiobarbituric acid reacting substances) with thiobarbituric acid (TBA) to form a pink coloured product. The colour intensity at $535 \mathrm{~nm}$ is directly proportional to TBARS concentration of the sample [17]. 1ml of (TCA) trichloro acetic acid (15\%) was measured into a test tube followed by the addition of $1 \mathrm{ml}$ of thiobarbituric acid and $50 \mu \mathrm{L}$ of the tissue homogenate. The mixture was incubated at $80{ }^{\circ} \mathrm{C}$ for 30 minutes in a water bath and allowed to cool for 2 minutes followed by centrifugation at $1000 \mathrm{xg}$ for 10 minutes. The absorbance of a clear supernatant was read spectrophotometrically at $535 \mathrm{~nm}$. TBARS concentration was expressed nmoles/gramme of tissue.

\section{F. Statistical Analysis}

Results were expressed as mean \pm SD. All data was subjected to one-way analysis of variance (ANOVA) and Tukey's post hoc test at 95\% level of significance using MINITAB 17 statistical software [18].

\section{RESULT}

\section{A. Effect of MTELE on Body Weight and Blood Glucose}

Induction of diabetes in rats led to a significant $(\mathrm{p}<0.05)$ reduction in the weight and significant $(\mathrm{p}<0.05)$ increase in the blood glucose level of rats over a period of seven weeks (Table I). The administration of MTELE at $50 \mathrm{mg} / \mathrm{kg}, 75 \mathrm{mg} / \mathrm{kg}$ and $100 \mathrm{mg} / \mathrm{kg}$ for seven weeks brought about amelioration of the two conditions. Weight of the rats were restored in a dose dependent manner while the blood glucose level was also reduced $50.6 \%, 62.1 \%$ and $72.68 \%$ compared to the initial glycaemia at diabetic induction respectively. There was a significant $(\mathrm{p}<0.05)$ reduction in the plasma glucose level of the normal control group and the normal group administered $100 \mathrm{mg} / \mathrm{kg}$ body weight daily dose for seven weeks.

TABLE I: EFFECT OF ORAL ADMINISTRATION OF ETHANOL LEAF EXTRACT OF M. TRIDENTATA ON BLOOD GLUCOSE LEVEL OF NORMAL AND DIABETIC RATS AFTER SEVEN WEEKS OF TREATMENT

\begin{tabular}{|c|c|c|c|c|}
\hline \multirow{2}{*}{ Treatments } & \multicolumn{2}{|c|}{ Body Weight (g) } & \multicolumn{2}{|c|}{ Plasma Glucose Level (mmol/L) } \\
\hline & Initial & Final & Initial & Final \\
\hline Normal Control & $131.80 \pm 5.99$ & $\begin{array}{c}156.01 \pm 3.32 \\
(18.37 \pm 1.42 \%)^{\mathrm{b}}\end{array}$ & $4.85 \pm 0.26$ & $\begin{array}{c}5.01 \pm 0.32 \\
(3.30 \pm 0.31 \%)^{\mathrm{a}}\end{array}$ \\
\hline Diabetic Control & $142.08 \pm 5.08$ & $\begin{array}{c}113.10 \pm 3.61 \\
(-20.40 \pm 2.01 \%)^{\mathrm{e}}\end{array}$ & $17.20 \pm 1.02$ & $\begin{array}{c}20.12 \pm 0.91 \\
(-16.98 \pm 1.42 \%)^{b}\end{array}$ \\
\hline $\begin{array}{l}\text { Normal + Extract } \\
\quad(100 \mathrm{mg} / \mathrm{kg})\end{array}$ & $128.50 \pm 8.06$ & $\begin{array}{c}161.16 \pm 9.51 \\
(25.42 \pm 5.93 \%)^{\mathrm{a}}\end{array}$ & $5.03 \pm 0.33$ & $\begin{aligned} 3.83 & \pm 0.26 \\
(-23.86 & \pm 2.11 \%)^{c}\end{aligned}$ \\
\hline $\begin{array}{l}\text { Diabetic + Extract } \\
(50 \mathrm{mg} / \mathrm{kg})\end{array}$ & $139.52 \pm 4.76$ & $\begin{array}{c}128.24 \pm 8.92 \\
(-8.08 \pm 1.10 \%)^{\mathrm{d}}\end{array}$ & $17.37 \pm 1.05$ & $\begin{array}{c}8.58 \pm 0.67 \\
(-50.6 \pm 4.32 \%)^{d}\end{array}$ \\
\hline $\begin{array}{c}\text { Diabetic + Extract } \\
(75 \mathrm{mg} / \mathrm{kg})\end{array}$ & $141.80 \pm 6.12$ & $\begin{array}{c}132.48 \pm 7.87 \\
(-6.57 \pm 1.15 \%)^{\mathrm{cd}}\end{array}$ & $17.52 \pm 1.03$ & $\begin{array}{c}6.50 \pm 0.48 \\
(-62.10 \pm 5.45 \%)^{e}\end{array}$ \\
\hline $\begin{array}{c}\text { Diabetic + Extract } \\
(100 \mathrm{mg} / \mathrm{kg})\end{array}$ & $140.64 \pm 6.06$ & $\begin{array}{c}133.31 \pm 5.73 \\
(-5.21 \pm 1.02 \%)^{\mathrm{c}}\end{array}$ & $17.68 \pm 1.07$ & $\begin{array}{c}4.83 \pm 0.33 \\
(-72.68 \pm 6.22 \%)^{e}\end{array}$ \\
\hline $\begin{array}{l}\text { Diabetic + Glibenclamide } \\
(1 \mathrm{mg} / \mathrm{kg})\end{array}$ & $138.25 \pm 9.60$ & $\begin{array}{c}131.05 \pm 4.24 \\
(-5.21 \pm 1.02 \%)^{\mathrm{c}}\end{array}$ & $17.25 \pm 1.04$ & $\begin{aligned} 5.70 & \pm 0.34 \\
(-66.97 & \pm 5.62 \%)^{c}\end{aligned}$ \\
\hline
\end{tabular}

${ }^{\mathrm{a}-\mathrm{e}}$ Values expressed as Mean \pm SD of five animals. Values in parenthesis which are $\%$ change for each treatment variables with different letters along a column are significantly $(\mathrm{p}<0.05)$ different from each other.

\section{B. Effect of MTELE on Tissue Enzymatic and Non-enzymatic Antioxidant Species (SOD, CAT, GSH and $T B A R S)$}

The activities of CAT and SOD in experimental rat tissues are shown in Table II. There was a significant $(\mathrm{p}<0.05)$ reduction in the activities of catalase and superoxide dismutase in the liver and kidney tissues as a result of diabetic induction in the diabetic control group. Treatment with different doses of MTELE (50, 75 and $100 \mathrm{mg} / \mathrm{kg}$ body weight) brought about a significant $(\mathrm{p}<0.05)$ increase in the activities of CAT and SOD in a dose dependent manner. There was also a significant increase $(p<0.05)$ in the activity of SOD in the kidney of the normal group administered $100 \mathrm{mg} / \mathrm{kg}$ /day dose of MTELE when compared with the normal group. 
European Journal of Advanced Chemistry Research www.ej-social.org

TABLE II: EFFECT OF ORAL ADMINISTRATION OF ETHANOL LEAF EXTRACTS OF M. TRIDENTATA ON SOME OXIDATIVE STRESS MARKERS IN LIVER AND KIDNEY OF NORMAL AND STREPTOZOTOCIN INDUCED DIABETIC RATS

\begin{tabular}{|c|c|c|c|c|c|c|c|c|}
\hline \multirow{2}{*}{ Treatments } & \multicolumn{2}{|c|}{ CAT (U/mg Protein) } & \multicolumn{2}{|c|}{ SOD (U/mg Protein) } & \multicolumn{2}{|c|}{ GSH ( $\mu$ mole/mg Protein) } & \multicolumn{2}{|c|}{ TBARS (mole/g tissue) } \\
\hline & Liver & Kidney & Liver & Kidney & Liver & Kidney & Liver & Kidney \\
\hline Normal Control & $84.19 \pm 5.33^{\mathrm{ab}}$ & $42.52 \pm 3.21^{\mathrm{ab}}$ & $6.38 \pm 0.31^{\mathrm{a}}$ & $15.31 \pm 1.22^{\mathrm{a}}$ & $43.43 \pm 3.27^{\mathrm{a}}$ & $30.83 \pm 2.61^{\mathrm{a}}$ & $0.48 \pm 0.04^{\mathrm{c}}$ & $0.75 \pm 0.07^{\mathrm{c}}$ \\
\hline Diabetic Control & $46.95 \pm 2.72^{\mathrm{c}}$ & $23.71 \pm 2.01^{\mathrm{c}}$ & $2.42 \pm 0.24^{\mathrm{c}}$ & $5.81 \pm 0.49^{c}$ & $22.07 \pm 2.01^{\mathrm{c}}$ & $16.55 \pm 1.01^{\mathrm{c}}$ & $1.00 \pm 0.09^{\mathrm{a}}$ & $1.92 \pm 0.11^{\mathrm{a}}$ \\
\hline $\begin{array}{l}\text { Normal + Extract } \\
\quad(100 \mathrm{mg} / \mathrm{kg})\end{array}$ & $88.78 \pm 6.54^{\mathrm{a}}$ & $44.84 \pm 3.16^{\mathrm{a}}$ & $6.56 \pm 0.54^{\mathrm{a}}$ & $15.74 \pm 1.15^{\mathrm{a}}$ & $46.76 \pm 4.14^{\mathrm{a}}$ & $30.86 \pm 2.82^{\mathrm{a}}$ & $0.43 \pm 0.03^{\mathrm{c}}$ & $0.72 \pm 0.06^{\mathrm{c}}$ \\
\hline $\begin{array}{c}\text { Diabetic + Extract } \\
(50 \mathrm{mg} / \mathrm{kg})\end{array}$ & $\begin{array}{c}79.36 \pm 6.29^{\mathrm{b}} \\
(69.2 \%)\end{array}$ & $\begin{array}{c}40.08 \pm 3.22^{b} \\
(69.0 \%)\end{array}$ & $\begin{array}{c}4.23 \pm 0.33^{\mathrm{b}} \\
(74.8 \%)\end{array}$ & $\begin{array}{c}10.15 \pm 1.22^{b} \\
(74.7 \%)\end{array}$ & $\begin{array}{c}38.94 \pm 3.17^{\mathrm{b}} \\
(76.4 \%)\end{array}$ & $\begin{array}{c}28.42 \pm 2.55^{\mathrm{a}} \\
\quad(71.7 \%)\end{array}$ & $\begin{array}{l}0.74 \pm 0.05^{\mathrm{b}} \\
(26.0 \%)\end{array}$ & $\begin{array}{c}0.96 \pm 0.08^{\mathrm{b}} \\
(50.0 \%)\end{array}$ \\
\hline $\begin{array}{c}\text { Diabetic + Extract } \\
(75 \mathrm{mg} / \mathrm{kg})\end{array}$ & $\begin{array}{c}80.63 \pm 5.87^{b} \\
(71.8 \%)\end{array}$ & $\begin{array}{c}40.72 \pm 2.86^{\mathrm{b}} \\
(71.7 \%)\end{array}$ & $\begin{array}{c}4.28 \pm 0.29^{b} \\
(76.9 \%)\end{array}$ & $\begin{array}{c}10.27 \pm 1.22^{\mathrm{b}} \\
(76.8 \%)\end{array}$ & $\begin{array}{c}41.68 \pm 3.77^{b} \\
(88.9 \%)\end{array}$ & $\begin{array}{c}29.18 \pm 2.46^{\mathrm{a}} \\
(76.3 \%)\end{array}$ & $\begin{array}{l}0.71 \pm 0.05^{\mathrm{b}} \\
(29.0 \%)\end{array}$ & $\begin{array}{l}0.90 \pm 0.08^{\mathrm{b}} \\
(53.1 \%)\end{array}$ \\
\hline $\begin{array}{l}\text { Diabetic + Extract } \\
\quad(100 \mathrm{mg} / \mathrm{kg})\end{array}$ & $\begin{array}{c}82.51 \pm 6.03^{b} \\
(75.6 \%)\end{array}$ & $\begin{array}{c}41.67 \pm 3.01^{\mathrm{ab}} \\
\quad(75.7 \%)\end{array}$ & $\begin{array}{c}4.34 \pm 0.35^{\mathrm{b}} \\
(78.1 \%)\end{array}$ & $\begin{array}{c}10.34 \pm 1.22^{\mathrm{b}} \\
(78.0 \%)\end{array}$ & $\begin{array}{c}43.86 \pm 3.83^{\mathrm{a}} \\
\quad(98.7 \%)\end{array}$ & $\begin{array}{c}29.82 \pm 2.71^{\mathrm{a}} \\
(80.2 \%)\end{array}$ & $\begin{array}{c}0.68 \pm 0.05^{\mathrm{b}} \\
(32.0 \%)\end{array}$ & $\begin{array}{c}0.89 \pm 0.07^{\mathrm{b}} \\
(53.7 \%)\end{array}$ \\
\hline $\begin{array}{c}\text { Diabetic + } \\
\text { Glibenclamide } \\
(1 \mathrm{mg} / \mathrm{kg})\end{array}$ & $\begin{array}{c}81.32 \pm 6.35^{\mathrm{b}} \\
(73.2 \%)\end{array}$ & $\begin{array}{c}41.07 \pm 3.21^{\mathrm{b}} \\
(73.2 \%)\end{array}$ & $\begin{array}{c}4.28 \pm 0.31^{\mathrm{b}} \\
(76.9 \%)\end{array}$ & $\begin{array}{c}10.27 \pm 1.22^{\mathrm{b}} \\
(76.8 \%)\end{array}$ & $\begin{array}{c}45.80 \pm 4.05^{\mathrm{a}} \\
(107.5 \%)\end{array}$ & $\begin{array}{l}31.14 \pm 2.83^{\mathrm{a}} \\
\quad(88.2 \%)\end{array}$ & $\begin{array}{c}0.50 \pm 0.04^{\mathrm{c}} \\
(50.0 \%)\end{array}$ & $\begin{array}{c}0.80 \pm 0.06^{\mathrm{b}} \\
(58.3 \%)\end{array}$ \\
\hline
\end{tabular}

${ }^{\mathrm{a}-\mathrm{c}}$ Values expressed as Mean \pm SD of five animals. Values with different letters along a column are significantly (p<0.05) different from each other while \% change in antioxidant status due to treatments are shown in parenthesis.

There was a significant $(\mathrm{p}<0.05)$ reduction in the concentration of GSH in liver and kidney tissues of the diabetic control group when compared to the normal group (Table II). Administration of varying doses of MTELE $(50 \mathrm{mg} / \mathrm{kg}, 75 \mathrm{mg} / \mathrm{kg}$ and $100 \mathrm{mg} / \mathrm{kg}$ body weight $)$ caused a significant $(\mathrm{p}<0.05)$ increase in the concentration of GSH in the liver and kidney tissues of rats treated with these doses. Also, the normal group administered $100 \mathrm{mg} / \mathrm{kg}$ body weight of MTELE showed a significant $(\mathrm{p}<0.05)$ increase in the concentration of GSH in the liver compared to the normal group. Moreover, there was a significant $(\mathrm{p}<0.05)$ increase in the level of TBARS in the liver and kidney tissues in diabetic condition. The seven weeks treatment with MTELE at $50 \mathrm{mg} / \mathrm{kg}, 75 \mathrm{mg} / \mathrm{kg}$ and $100 \mathrm{mg} / \mathrm{kg}$ body weight doses caused a significant $(p<0.001)$ reduction in TBARS level in these tissues at the different doses administered. A significant $(p<0.05)$ reduction in the TBARS level in liver of normal rats administered $100 \mathrm{mg} / \mathrm{kg}$ body weight dose of MTELE was noticed compared to the normal control group signifying the strong antioxidant potential of the extract especially in the liver.

\section{DISCUSSION}

Herbal medicine had been a well embraced alternative form of medication for different kinds of ailment in the developing nations. The search for potent therapeutic compounds in plants continues to be of immense concern because of the nature of the source material. Natural drugs are found to have little or fewer side effects (if any) compared to the synthetic ones. Induction of diabetes mellitus using streptozotocin in rat had led to a very high increase in the plasma glucose with corresponding decrease in the body weight. Steptozotocin is a cytotoxic agent causing alkylation of DNA in the cells of the pancreas resulting in the degranulation and destruction of the islet's beta cells thus leading to acute decrease in the level of insulin, beta cell nicotinamide adenine dinucleotide and release of free radicals like nitric oxide (NO) which further aggravates DNA strand damage of the pancreatic cell [19] and [20]. Hyperglyceamia and polydipsia are known as the major characterization indices of diabetes mellitus. In this study, the extract (at $50 \mathrm{mg} / \mathrm{kg}, 75 \mathrm{mg} / \mathrm{kg}$ and $100 \mathrm{mg} / \mathrm{kg}$ body weight doses were able to ameliorate these indices considerably in a dose dependent manner. This is in consonance to the work of [1] who reported the same trend after administration of aqueous root extract of Merremia tridentata (Linn) to streptozotocin induced diabetic rats at $50 \mathrm{mg} / \mathrm{kg}, 100 \mathrm{mg} / \mathrm{kg}$ and $150 \mathrm{mg} / \mathrm{kg}$ body weight doses. The extract could be noted for good hypoglycaemic and nutrient utilization potential as the normal rat administered with $100 \mathrm{mg} / \mathrm{kg}$ dose manifested significant $(\mathrm{p}<0.05)$ better potential in percentage hyperglycemic and weight change respectively. This may be as a result of enhancement of carbohydrate metabolism by the extract to supply the needed energy. In diabetic state, there occurred a situation of shift from carbohydrate as an immediate and primary energy source to protein and fat which naturally depletes their storage that could have been used for body building, growth and some other biochemical activities. Moreover, glycation of protein had also been reported in diabetic conditions. The anti-hyperglycaemia and amelioration of tissue wastage observed in this study could be an indication of the ability of the extract to enhance some enzymes of glycolysis, reverts gluconeogenesis and protein glycation so that glucose could readily be burnt for energy and protein made available for replacement of worn-out cells, synthesis of other proteins, growth and development.

Diabetic hyperglycaemia usually results in an increase in free radical production by a mechanism involving glucose oxidation followed by protein glycation and oxidative degeneration [21]. Oxidative stress had been reported to be the etiogenesis of the different kinds of complications encountered in diabetes [22][26]. Tissue damage and dysfunction is reportedly caused by free radical mediated attack on the membrane through peroxidation of the unsaturated membrane lipids [8], [27]. Our study revealed the high antioxidant potential of MTELE. There was a significant $(\mathrm{p}<0.05)$ increase in the activities of catalase, superoxide 
dismutase, and in the level of glutathione and significant $(\mathrm{p}<0.05)$ reduction in the level of peroxidation indicated by the output of thiobartbituric acid reacting substances in the liver and kidney tissues. These observations confirmed the reports of [1] and [28] which claimed that Merremia tridentata (Linn) contains flavonoids such as Diosmetin and Luteolin which are potent and have free radical scavenging abilities. Merremia spp are known for their powerful antioxidant potential and regarded as one of the best of such [29]. This justifies its use as anti-inflammatory, anti-ulcer, wound healing, anti-arthritic, immunestimulatory and anti-diabetic regimen.

\section{CONCLUSION}

The study clearly proves the ability of the ethanol leaf extract of $M$. tridentata (Linn) to ameliorate the regime of diabetes mellitus and its attendant complication therefore justifying its use in folk medicine for the treatment of sugar related disease. Moreover, effort should be geared towards isolation, purification, and characterization of the bioactive compound(s) responsible for the anti-diabetic effect coupled with the elucidation of the possible mechanisms of action.

\section{REFERENCES}

[1] K. Arunachalam, and T. Parimelazhagan, Antidiabetic activity of aqueous root extract of Merremia tridentata (L.) Hall. $f$. in streptozotocin-induced-diabetic rats. Asian Pacific Journal of Tropical Medicine, 2012; 5(3): 175-179.

[2] F. Giacco and M. Brownlee, Oxidative stress and diabetic complications. Circulation Research, 2010; $107(9): 1058-1070$.

[3] J.W. Baynes and S. R. Thorpe, Role of oxidative stress in diabetic complications: a new perspective on an old paradigm. Diabetes, 1999; 48:1-9.

[4] A. Ceriello, Oxidative stress and diabetes-associated complications. Endocrine Practice, 2006; 12(1):60-62.

[5] R., Nimenibo-Uadia and A.U., Osagie, Effect of Ficus exasperata (Vahl) Aqueous leaf extract on normal and Alloxan diabetic Rats. Nigerian Journal of Biochemistry and Molecular Biology, 2001; 16 (1): 67-71.

[6] S. E. Atawodi. and A. Muazu, Effect of aqueous extract of Psidium guajava on glucose levels in normoglycaemic and alloxaninduced diabetic rats. Nigerian Journal of Biochemistry and Molecular Biology, 2003; 13(2):125-128.

[7] M. Jung M, Park H. C. Lee, Y. H. Kang, E. S. Kang and S. K. Kim, Antidiabetic agents from medicinal plants. Curr Med Chem, 2006; 13:1203-1218.

[8] S. O. Oyedemi, E. A. Adewusi, O. A, Aiyegoro, D. A. Akinpelu, Antidiabetic and haematological effect of aqueous extract of stem bark of Afzelia africana (Smith) on streptozotocin-induced diabetic Wistar rats. Asian Pac J Trop Biomed, 2011; 1(5):353358 .

[9] R. Nimenibo-Uadia, and K. Nwachukwu, Biochemical Evaluation of Harungana Madagascariensis Lam Aqueous Leaf Extract in Diabetic Rats: International Research Journal of Natural Sciences, 2017;5(2):1-11.

[10] M. Kamalutheen, S. Gopalakrishnan and T.S. Ismail, Anti-inflammatory and anti-arthritic activities of Merremia tridentata (L.) Hall. F. E-J Chem, 2009; 6: 943-948.

[11] O. H. Lowry, N. J. Rosebrough, A. L. Farr, and R. J. Randall, Protein measurement with the Folin phenol reagent. J. Biol. Chem. 1951; 193: 265-275.

[12] H. P. Misra, and I. Fridovich, The role of superoxide anion in the antioxidant of epinephrine and simple assay for SOD. $J$ Biol Chem 1972; 247: 3170-3175.

[13] A. K. Sinha, Colorimetric assay of catalase. Anal Biochem 1972; 47: 389-394.

[14] U.N. Tripathi and D. Chandra. Anti-hyperglycemic and anti-oxidative effect of aqueous extract of Momordica charantia pulp and Trigonella foenum graecum seed in alloxan-induced diabetic rats. Indian J. Biochem Biophys., 2010; 47:227-233.

[15] G.L. Ellman. Tissue sulphydryl groups. Arch Biochem Biophys. 1995; 82:70-77.

[16] R. Rajagopalan, A. Kode, S. V. Penumatha, N. R. Kallikat and P. M. Venugopal, Comparative effects of curcumin on alcohol and PUFA induced oxidative stress. J. Pharm Pharmaceut Sci., 2004; 7: 274-283.

[17] H. Okhawa, N. Ohishi, and K. Yagi, Assay for lipid peroxides in animal tissues by thiobarbituric acid reaction. Analytical Biochemistry, 1979; 95(2): 351-358.

[18] O. A. Adebiyi, D.A. Ameh, E. Onyike and D. B. James, Acute and chronic toxicity study of ethanol leaf extract of Merremia tridentata (Linn) Hillier F. European Journal of Advanced Chemistry Research 2021;2(3):14-20.

[19] X. F. Zhang, and B.K. Tan, Antihyperglyceamic and anti-oxidant properties of Andrographis paniculata in normal and diabetic rats, Clin Exp Pharmacol Physiol, 2000;27:358-363.

[20] S. Lenzen, The mechanism of alloxan and streptozotocin-induced Diabetes, Diabetologia, 2008; 51:216-226.

[21] J. V. Hunt, R. T. Dean, and S. P. Wolff, Hydroxyl radical production and autoxidative glycosylation. Glucose autoxidation as the cause of protein damage in the experimental glycation model of diabetes mellitus and ageing. Biochem J; 1988; 256(1): 205212 .

[22] J. W. Baynes, Role of oxidative stress in development of complications in diabetes. Diabetes, 1991; 40:243-250.

[23] R. A. Kowluru, T. S. Kern, and R Engerman, Abnormalities of retinal metabolism in diabetes or experimental galactosemia IV. Antioxidant defense system. Free Radical Biol Med, 1997; 22: 587-592.

[24] T.J. Lyons and A. J. Jenkins (1997). Glycation, oxidation and lipoxidation in the development of diabetes: a carbonyl stress hypothesis. Diabetes Rev 1997; 5:365-391.

[25] O. P. Upahyay, R.M. Singh, and K. Dutta, Studies on anti-diabetic medicinal plants used in Indian folklore. Argyavaidyan, 1996; 9(3):159-167.

[26] S. Banerjee, H..Singh and T. K. Chatterjee Evaluattion and antidiabetic and antihyperlipidemic potential of methanolic extract of Juniperus communis (L) in streptozotocin-nicotinamide induced diabetic rats. Int J Pharma Bio Sci; 2013; 4(3):10-17.

[27] K. Ravi, B. Ramachandran and S, Subramanian, Effect of Eugenia jambolana seed kernel on antioxidant defense system in streptozotocin-induced diabetes in rats. Life Sci; 2004;75: 2717-2731.

[28] S. Adikay, R. Radha and B. Koganti, Effect of methanolic extract of aerial parts of Merremia tridentata on gentamicin-induced nephrotoxicity in rats, Natural Products: An Indian Journal, 2008;4(2):174-176.

[29] K. Sowndhararajan, J. M. Joseph, K. Arunachalam, and S. Manian. Evaluation of Merremia tridentata (L.) Hallier F for in vitro antioxidant activity. Food Sci. Biotechnol 2010:19(3): 663-669. 